\title{
Asaia krungthepensis sp. nov., an acetic acid bacterium in the $\alpha$-Proteobacteria
}

\author{
Pattaraporn Yukphan, ${ }^{1}$ Wanchern Potacharoen, ${ }^{1}$ Somboon Tanasupawat, ${ }^{2}$ \\ Morakot Tanticharoen ${ }^{1}$ and Yuzo Yamada ${ }^{1,3} \dagger$
}

Correspondence

Yuzo Yamada

yamada-yuzo@mub.biglobe.ne.jp

\author{
${ }^{1}$ BIOTEC Culture Collection, BIOTEC Central Research Unit, National Centre for Genetic \\ Engineering and Biotechnology, National Science and Technology Development Agency, \\ 113 Thailand Science Park, Phaholyothin Road, Klong 1, Klong Luang, Pathumthani 12120, \\ Thailand \\ ${ }^{2}$ Department of Microbiology, Faculty of Pharmaceutical Sciences, Chulalongkorn University, \\ 254 Phayathai Road, Wangmai, Pathumwan, Bangkok 10330, Thailand \\ ${ }^{3}$ JICA (Japan International Cooperation Agency, Tokyo, Japan) Senior Overseas Volunteer; \\ Laboratory of General and Applied Microbiology, Department of Applied Biology and \\ Chemistry, Faculty of Applied Bioscience, Tokyo University of Agriculture, 1-1-1 Sakuragaoka, \\ Setagaya-ku, Tokyo 156-8502, Japan
}

Three bacterial strains were isolated from flowers collected in Bangkok, Thailand, by an enrichment-culture approach for acetic acid bacteria. Phylogenetic analysis based on $16 \mathrm{~S}$ rRNA gene sequences showed that the isolates were located in the lineage of the genus Asaia but constituted a cluster separate from the type strains of Asaia bogorensis and Asaia siamensis. The DNA base composition of the isolates was $60 \cdot 2-60.5 \mathrm{~mol} \% \mathrm{G}+\mathrm{C}$, with a range of $0.3 \mathrm{~mol} \%$. The isolates constituted a taxon separate from Asaia bogorensis and Asaia siamensis on the basis of DNA-DNA relatedness. The isolates had morphological, physiological, biochemical and chemotaxonomic characteristics similar to those of the type strains of Asaia bogorensis and Asaia siamensis, but the isolates grew on maltose. The major ubiquinone was $\mathrm{Q}_{10}$. On the basis of the results obtained, the name Asaia krungthepensis sp. nov. is proposed

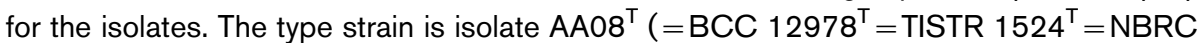
$100057^{\top}=$ NRIC $0535^{\top}$ ), which had a DNA G $+\mathrm{C}$ content of $60 \cdot 3 \mathrm{~mol} \%$ and was isolated from a heliconia flower ('paksaasawan' in Thai; Heliconia sp.) collected in Bangkok, Thailand.
The genus Asaia was introduced with a single species, Asaia bogorensis, as the fifth genus of the family Acetobacteraceae (Yamada et al., 2000). Asaia siamensis, the second species, was described by Katsura et al. (2001). Strains assigned to the genus Asaia are characterized by poor or non-existent production of acetic acid from ethanol and by the absence of growth in the presence of $0.35 \%$ acetic acid (v/v). On the other hand, strains of the genera Acetobacter, Gluconobacter, Acidomonas, Gluconacetobacter and Kozakia produce large amounts of acetic acid from ethanol and grow in the presence of $0.35 \%$ acetic acid. According to Yamada et al. (2000) and Katsura et al. (2001), strains of the genus Asaia have been isolated mostly from tropical flowers. During the

†Present address: 2-3-21 Seinancho, Fujieda, Shizuoka-ken 426-0063, Japan.

Published online ahead of print on 13 June 2003 as DOI 10.1099/ ijs.0.02734-0,

The GenBank/EMBL/DDBJ accession numbers for the 16S rRNA gene sequences of Asaia krungthepensis $\mathrm{AAO}^{\top}{ }^{\mathrm{T}}, \mathrm{AA} 09$ and $\mathrm{AA06}$ are respectively AB102953, AB102954 and AB102955. course of our studies on acetic acid bacteria isolated from flowers collected in Thailand, we found that three isolates constitute a novel species; this paper describes Asaia krungthepensis sp. nov.

Three bacterial strains were isolated from heliconia flowers ('paksaasawan' in Thai; Heliconia sp.) collected in Bangkok, Thailand, by an enrichment-culture approach using a sucrose medium, which was composed of $2 \cdot 0 \%$ sucrose, $0 \cdot 3 \%$ peptone, $0 \cdot 3 \%$ yeast extract and $0 \cdot 3 \%$ acetic acid $(\mathrm{v} / \mathrm{v})$ and adjusted to $\mathrm{pH} 3 \cdot 5$. When bacterial growth was found in the sucrose medium, micro-organisms were streaked on agar plates containing $2.0 \%$ D-glucose, $0.5 \%$ ethanol (v/v), $0 \cdot 3 \%$ peptone, $0 \cdot 3 \%$ yeast extract, $0 \cdot 7 \%$ $\mathrm{CaCO}_{3}$ and $1 \cdot 2 \%$ agar (w/v). These acetic acid bacteria were selected as acid-producing bacterial strains that formed clear zones around colonies on agar plates. The three isolates, $\mathrm{AA08}^{\mathrm{T}}\left(=\mathrm{BCC} 12978^{\mathrm{T}}\right), \mathrm{AA} 09(=\mathrm{BCC} 12979)$ and AA06 ( = BCC 12977), were cultured at $30^{\circ} \mathrm{C}$ on agar slants comprising glucose/ethanol/ $\mathrm{CaCO}_{3} /$ agar medium (GECA medium) that contained $2.5 \% \mathrm{D}$-glucose, $0.5 \%$ ethanol, 
$0.5 \%$ peptone, $0 \cdot 3 \%$ yeast extract, $0.7 \% \mathrm{CaCO}_{3}$ and $1 \cdot 2 \%$ agar and were maintained at $4{ }^{\circ} \mathrm{C}$. Asaia bogorensis IFO $16594^{\mathrm{T}}$ and Asaia siamensis IFO $16457^{\mathrm{T}}$ were used as reference strains, together with Acetobacter aceti IFO $14818^{\mathrm{T}}$, Gluconobacter oxydans IFO $14819^{\mathrm{T}}$ and Gluconacetobacter liquefaciens IFO $12388^{\mathrm{T}}$.

Morphological, physiological and biochemical characteristics were examined by using the methods reported by Asai et al. (1964), Yamada et al. $(1999,2000)$ and Katsura et al. (2001). The phenotypic characteristics of the three isolates are described in the species description. The isolates were different from the type strains of Asaia bogorensis and Asaia siamensis in acid production from maltose and growth on maltose: the isolates produced acid weakly from maltose, with one exception, and grew on maltose, but their growth was not intense (Table 1).

Isoprenoid quinones were extracted from bacterial cells and purified by the method of Yamada et al. (1969). Ubiquinone isoprenologues were quantified by reversedphase HPLC (Tamaoka et al., 1983). The three isolates (AA08 ${ }^{\mathrm{T}}, \mathrm{AA} 09$ and AA06) had $\mathrm{Q}_{10}$ as the major quinone. The ubiquinone system of isolate $\mathrm{AA} 08^{\mathrm{T}}$ was composed of $1 \% \mathrm{Q}_{7}, 2 \% \mathrm{Q}_{8}, 16 \% \mathrm{Q}_{9}$ and $81 \% \mathrm{Q}_{10}$.

Gene fragments specific for $16 \mathrm{~S}$ rRNA-encoding regions were amplified by means of a PCR as described previously (Yamada et al., 2000; Katsura et al., 2001; Kawasaki et al., 1993). Two primers, 20F (5'-GAGTTTGATCCTGGCTCAG-3', positions 9-27) and 1500R (5'-GTTACCTTGTTACGACTT-3', positions 1509-1492), were used. Positions in the rRNA gene fragments were based on the Escherichia coli numbering system (accession number V00348; Brosius et al., 1981).

Amplified 16S rRNA genes were sequenced directly with

Table 1. Characteristics that differentiate Asaia krungthepensis, Asaia bogorensis and Asaia siamensis

Strains: 1, Asaia krungthepensis $\mathrm{AA}^{\mathrm{T}} 8^{\mathrm{T}}$; 2, Asaia krungthepensis AA09; 3, Asaia krungthepensis AA06; 4, Asaia bogorensis IFO $16594^{\mathrm{T}}$; 5, Asaia siamensis IFO $16457^{\mathrm{T}}$. +, Positive; -, negative; $\mathrm{W}$, weak. All strains showed weak oxidation of acetate and lactate and no growth in the presence of acetic acid $(0 \cdot 35 \%, \mathrm{v} / \mathrm{v})$.

\begin{tabular}{|lccccc|}
\hline Characteristic & $\mathbf{1}$ & $\mathbf{2}$ & $\mathbf{3}$ & $\mathbf{4}$ & $\mathbf{5}$ \\
\hline $\begin{array}{l}\text { Dihydroxyacetone formation } \\
\text { from glycerol }\end{array}$ & + & + & + & + & $\mathrm{W}$ \\
Acid production from: & & & & & \\
$\quad \begin{array}{l}\text { Dulcitol } \\
\text { Maltose }\end{array}$ & + & + & + & + & - \\
$\quad$ Ethanol & $\mathrm{W}$ & $\mathrm{W}$ & - & - & - \\
$\begin{array}{l}\text { Growth on maltose } \\
\text { G }+ \text { C content of DNA (mol\%) }\end{array}$ & $-60 \cdot 3$ & $60 \cdot 2$ & $60 \cdot 5$ & $60 \cdot 2^{*}$ & $59 \cdot 3^{*}$ \\
\hline
\end{tabular}

*Data from Yamada et al. (2000) and Katsura et al. (2001). an ABI PRISM BigDye Terminator cycle sequencing ready reaction kit on an ABI PRISM model 310 Genetic Analyzer (both from Applied Biosystems). The following primers were used for sequencing: 20F, 1500R, 520F ( $5^{\prime}$ CAGCAGCCGCGGTAATAC-3'; positions 519-536), 520R (5'-GTATTACCGCGGCTGCTG-3'; positions 536-519), 920F (5'-AAACTCAAATGAATTGACGG-3'; positions 907-926) and 920R (5'-CCGTCAATTCATTTGAGTTT3'; positions 926-907). Multiple alignments of the sequences were carried out with the program CLUSTAL X (version 1.81) (Thompson et al., 1997). Distance matrices for the aligned sequences were calculated by using the two-parameter method of Kimura (1980). The neighbourjoining method was used to construct a phylogenetic tree (Saitou \& Nei, 1987). Comparison of the sequence data obtained was made on 1376 bases (Yamada et al., 2000) and the robustness for individual branches was estimated by bootstrapping with 1000 replications (Felsenstein, 1985). Asaia krungthepensis sp. nov. isolates AA08 ${ }^{\mathrm{T}}, \mathrm{AA} 09$ and AA06 were located in the lineage of the genus Asaia, but constituted a cluster separate from the type strains of the known species of the genus Asaia, Asaia bogorensis and Asaia siamensis (Fig. 1).

Pairwise sequence similarities (\%) of $16 \mathrm{~S}$ rRNA genes among acetic acid bacteria, including the novel isolates, were determined for 1382 bases. Among the three isolates, the sequence similarities were $100 \%$. Asaia krungthepensis AA08 ${ }^{\mathrm{T}}$ (=BCC $12978^{\mathrm{T}}$ ) showed respectively $99 \cdot 6$, 99.5, $97 \cdot 3,96 \cdot 2,96 \cdot 2,95 \cdot 9$ and $95 \cdot 4 \%$ sequence similarity to the type strains of Asaia bogorensis, Asaia siamensis, Kozakia baliensis, Acetobacter aceti, Gluconacetobacter liquefaciens, Acidomonas methanolica and Gluconobacter oxydans.

Extraction and isolation of bacterial DNA were performed using the modified method of Marmur (1961) (Saito \& Miura, 1963; Ezaki et al., 1983). DNA base composition was determined by the method of Tamaoka \& Komagata (1984). The DNA $G+C$ contents of the three isolates $\left(\mathrm{AA} 08^{\mathrm{T}}, \mathrm{AA} 09\right.$ and AA06) were respectively $60 \cdot 3,60 \cdot 2$ and $60.5 \mathrm{~mol} \%$, with a range of $0.3 \mathrm{~mol} \%$.

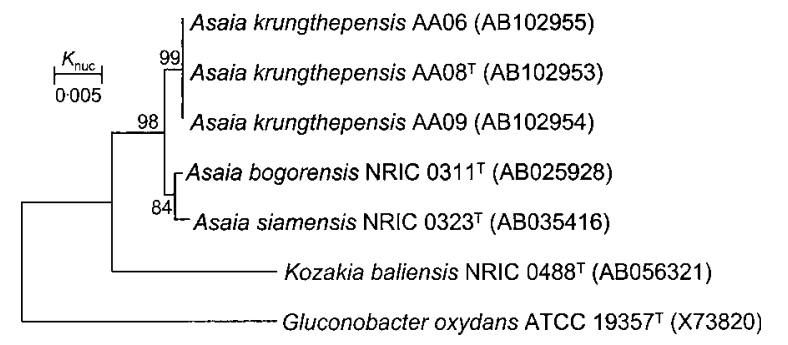

Fig. 1. Phylogenetic relationships of Asaia krungthepensis sp. nov. based on $16 \mathrm{~S}$ rRNA gene sequences. Gluconobacter oxydans ATCC $19357^{\top}$ was used as an outgroup. Numbers at nodes indicate bootstrap percentages derived from 1000 replications. 
DNA-DNA hybridization was carried out using the photobiotin-labelling method with microdilution wells as described by Ezaki et al. (1989). DNA-DNA relatedness (\%) was determined using the colorimetric method (Verlander, 1992). Isolated single-stranded and labelled DNAs were hybridized with DNAs from test strains in $2 \times$ SSC and $50 \%$ formamide at $48.0^{\circ} \mathrm{C}$ for $12 \mathrm{~h}$. The colour intensity was measured as $A_{450}$ on a Bio-Rad model 3550 microplate reader. Labelled DNA from Asaia krungthepensis AA08 ${ }^{\mathrm{T}}$ $\left(=\mathrm{BCC} 12978^{\mathrm{T}}\right)$ showed respectively $100,100,100,38,40$ and $9 \%$ DNA-DNA relatedness to isolates AA08 ${ }^{\mathrm{T}}$, AA09 and AA06, Asaia bogorensis IFO $16594^{\mathrm{T}}$, Asaia siamensis IFO $16457^{\mathrm{T}}$ and Gluconobacter oxydans IFO $14819^{\mathrm{T}}$. When isolate AA06 DNA was labelled, the DNA-DNA similarities were respectively $100,100,100,31,36$ and $5 \%$. Asaia bogorensis IFO $16594^{\mathrm{T}}$ and Asaia siamensis IFO $16457^{\mathrm{T}}$ had respectively 27 and $17 \%, 36$ and $22 \%, 29$ and $18 \%$, 100 and $22 \%, 32$ and $100 \%$ and 6 and $4 \%$ DNA-DNA relatedness to isolates $\mathrm{AA} 08^{\mathrm{T}}$, AA09 and AA06, Asaia bogorensis $16594^{\mathrm{T}}$, Asaia siamensis IFO $16457^{\mathrm{T}}$ and Gluconobacter oxydans IFO $14819^{\mathrm{T}}$.

The acetic acid bacteria are currently classified into six genera: Acetobacter (the type genus), Gluconobacter, Acidomonas, Gluconacetobacter, Asaia and Kozakia (Yamada et al., 2000; Lisdiyanti et al., 2002). In the phylogenetic tree based on 16S rRNA-gene sequences, the three isolates $\left(\mathrm{AA} 08^{\mathrm{T}}, \mathrm{AA} 09\right.$ and AA06) were located in the lineage of the genus Asaia, but constituted a cluster separate from the cluster comprising Asaia bogorensis IFO $16594^{\mathrm{T}}$ and Asaia siamensis IFO $16457^{\mathrm{T}}$. The DNA base compositions of the isolates $(60 \cdot 2-60 \cdot 5 \mathrm{~mol} \% \mathrm{G}+\mathrm{C})$ were almost identical to that of Asaia bogorensis IFO $16594^{\mathrm{T}}(60 \cdot 2 \mathrm{~mol} \% \mathrm{G}+\mathrm{C})$. The DNA-DNA relatedness (40-17\%) of the isolates revealed a taxon separate from Asaia bogorensis and Asaia siamensis. Phenotypically, the three isolates can be distinguished from the type strains of the known species (Table 1). The isolates were different from Asaia siamensis IFO $16457^{\mathrm{T}}$ in terms of acid production from dulcitol. The three isolates showed varying growth responses on maltose, which also differed from those of the type strains of the known species, and the growth was not intense for any strain. Consequently, the three isolates can be distinguished genetically and phenotypically from the known species of the genus Asaia, and should be classified as a novel species. The name Asaia krungthepensis sp. nov. is proposed for the three isolates.

\section{Description of Asaia krungthepensis sp. nov.}

Asaia krungthepensis (krung.thep.en'sis. N.L. fem. adj. krungthepensis of or pertaining to Krungthep, the Thai name of Bangkok, Thailand, where the type strain was isolated).

Cells are Gram-negative rods, measuring 0.6-1.0 $\times 1 \cdot 0$ $2.5 \mu \mathrm{m}$ on GECA medium. Motile with peritrichous flagella. Colonies are pink, shiny, smooth and raised with an entire margin on GECA medium. Strictly aerobic. Grows at pH 3.0 and 3.5 at $30^{\circ} \mathrm{C}$ on $\mathrm{CaCO}_{3}$ - and agar-free GECA medium. Oxidizes acetate and lactate to carbon dioxide and water, but the activity is not intense. No production of acetic acid from ethanol. No growth on methanol. Produces 2-keto-D-gluconate and 5-keto-D-gluconate from D-glucose, but not 2,5-diketo-D-gluconate. Grows on glutamate agar and mannitol agar. Vigorous growth on a vitamin-free glucose/ $\left(\mathrm{NH}_{4}\right)_{2} \mathrm{SO}_{4}$ medium, but not on a vitamin-free ethanol/ $\left(\mathrm{NH}_{4}\right)_{2} \mathrm{SO}_{4}$ medium. Produces dihydroxyacetone. Acid is produced from D-glucose, D-mannose, D-galactose, D-fructose, L-sorbose, D-xylose, L-arabinose, L-rhamnose, D-mannitol, D-sorbitol, dulcitol, meso-erythritol, glycerol, melibiose and sucrose. Acid production is weak from Darabinose, maltose and raffinose and acid is not produced from lactose or ethanol. Grows on D-glucose, D-galactose, D-fructose, L-sorbose, D-xylose, L-arabinose, D-mannitol, D-sorbitol, dulcitol, meso-erythritol, glycerol and sucrose, but grows hardly at all on D-mannose, D-arabinose, L-rhamnose, melibiose and raffinose. No growth is shown on lactose and ethanol. Grows on maltose, but the growth is not intense. The major ubiquinone is $\mathrm{Q}_{10}$. The $\mathrm{G}+\mathrm{C}$ content of the DNA is $60 \cdot 2-60 \cdot 5 \mathrm{~mol} \%$, with a range of $0 \cdot 3 \mathrm{~mol} \%$.

The type strain, isolate AA $08^{\mathrm{T}}$, has a DNA G $+\mathrm{C}$ content of $60.3 \mathrm{~mol} \%$ and was isolated from a heliconia flower collected in Bangkok, Thailand. The type strain has been deposited in the BIOTEC Culture Collection, BIOTEC Central Research Unit, National Centre for Genetic Engineering and Biotechnology, National Science and Technology Development Agency, Pathumthani, Thailand, as BCC $12978^{\mathrm{T}}$, in the culture collection of the National Biological Resource Centre, Department of Biotechnology, National Institute of Technology and Evaluation, Kisarazu, Chiba-ken, Japan, as NBRC $100057^{\mathrm{T}}$, in the NODAI Culture Collection, Tokyo University of Agriculture, Setagaya-ku, Tokyo, Japan, as NRIC $0535^{\mathrm{T}}$ and in the culture collection of the Thailand Institute of Scientific and Technological Research, Bangkok, Thailand, as TISTR $1524^{\mathrm{T}}$.

\section{Acknowledgements}

We are grateful to the Thailand Institute of Scientific and Technological Research, Bangkok, Thailand, for the use of a DNA sequencer. We also thank the Institute for Fermentation, Osaka (IFO), Osaka, Japan, for supplying cultures of reference strains. Thanks are also due to Miss Somchit Am-in (Department of Applied Biology, Faculty of Science and Technology, Rajabhat Institute Suan Sunandha, Bangkok, Thailand) for her technical assistance. This study was supported, in part, by the Biodiversity Research and Training Programme, Bangkok, Thailand.

\section{References}

Asai, T., lizuka, H. \& Komagata, K. (1964). The flagellation and taxonomy of genera Gluconobacter and Acetobacter with reference to the existence of intermediate strains. J Gen Appl Microbiol 10, 95-126.

Brosius, J., Dull, T. J., Sleeter, D. D. \& Noller, H. F. (1981). Gene organization and primary structure of a ribosomal RNA operon from Escherichia coli. J Mol Biol 148, 107-127.

Ezaki, T., Yamamoto, N., Ninomiya, K., Suzuki, S. \& Yabuuchi, E. (1983). Transfer of Peptococcus indolicus, Peptococcus asaccharolyticus, 
Peptococcus prevotii, and Peptococcus magnus to the genus Peptostreptococcus and proposal of Peptostreptococcus tetradius sp. nov. Int J Syst Bacteriol 33, 683-698.

Ezaki, T., Hashimoto, Y. \& Yabuuchi, E. (1989). Fluorometric deoxyribonucleic acid-deoxyribonucleic acid hybridization in microdilution wells as an alternative to membrane filter hybridization in which radioisotopes are used to determine genetic relatedness among bacterial strains. Int J Syst Bacteriol 39, 224-229.

Felsenstein, J. (1985). Confidence limits on phylogenies: an approach using the bootstrap. Evolution 39, 783-791.

Katsura, K., Kawasaki, H., Potacharoen, W., Saono, S., Seki, T., Yamada, Y., Uchimura, T. \& Komagata, K. (2001). Asaia siamensis sp. nov., an acetic acid bacterium in the $\alpha$-Proteobacteria. Int J Syst Evol Microbiol 51, 559-563.

Kawasaki, H., Hoshino, Y., Hirata, A. \& Yamasato, K. (1993). Is intracytoplasmic membrane structure a generic criterion? It does not coincide with phylogenetic interrelationships among photosynthetic purple nonsulfur bacteria. Arch Microbiol 160, 358-362.

Kimura, M. (1980). A simple method for estimating evolutionary rates of base substitutions through comparative studies of nucleotide sequences. J Mol Evol 16, 111-120.

Lisdiyanti, P., Kawasaki, H., Widyastuti, Y., Saono, S., Seki, T., Yamada, Y., Uchimura, T. \& Komagata, K. (2002). Kozakia baliensis gen. nov., sp. nov., a novel acetic acid bacterium in the $\alpha$-Proteobacteria. Int J Syst Evol Microbiol 52, 813-818.

Marmur, J. (1961). A procedure for isolation of deoxyribonucleic acid from micro-organisms. J Mol Biol 3, 208-218.

Saito, H. \& Miura, K. (1963). Preparation of transforming deoxyribonucleic acid by phenol treatment. Biochim Biophys Acta 72, 619-629.
Saitou, N. \& Nei, M. (1987). The neighbor-joining method: a new method for reconstructing phylogenetic trees. Mol Biol Evol 4, 406-425.

Tamaoka, J. \& Komagata, K. (1984). Determination of DNA base composition by reversed-phase high-performance liquid chromatography. FEMS Microbiol Lett 25, 125-128.

Tamaoka, J., Katayama-Fujimura, Y. \& Kuraishi, H. (1983). Analysis of bacterial menaquinone mixtures by high-performance liquid chromatography. J Appl Bacteriol 54, 31-36.

Thompson, J. D., Gibson, T. J., Plewniak, F., Jeanmougin, F. \& Higgins, D. G. (1997). The CLUSTAL_X windows interface: flexible strategies for multiple sequence alignment aided by quality analysis tools. Nucleic Acids Res 25, 4876-4882.

Verlander, C. P. (1992). Detection of horseradish peroxidase by colorimetry. In Nonisotopic DNA Probe Techniques, pp. 185-201. Edited by L. J. Kricka. New York: Academic Press.

Yamada, Y., Aida, K. \& Uemura, T. (1969). Enzymatic studies on the oxidation of sugar and sugar alcohol. V. Ubiquinone of acetic acid bacteria and its relation to classification of Gluconobacter and Acetobacter, especially of the so-called intermediate strains. J Gen Appl Microbiol 15, 186-196.

Yamada, Y., Hosono, R., Lisdiyanti, P., Widyastuti, Y., Saono, S., Uchimura, T. \& Komagata, K. (1999). Identification of acetic acid bacteria isolated from Indonesian sources, especially of isolates classified in the genus Gluconobacter. J Gen Appl Microbiol 45, 23-28.

Yamada, Y., Katsura, K., Kawasaki, H., Widyastuti, Y., Saono, S., Seki, T., Uchimura, T. \& Komagata, K. (2000). Asaia bogorensis gen. nov., sp. nov., an unusual acetic acid bacterium in the $\alpha$-Proteobacteria. Int J Syst Evol Microbiol 50, 823-829. 